\title{
Bureaucracy Reforms of Public Service: Case Study of Governance Structuring of Passport Issuance System at Class I Makassar Immigration Office
}

\author{
Uddin B. Sore ${ }^{1}$ \\ Rahmat $^{2}$ \\ Muh. Jufri2 \\ Muhammad Idris Patarai ${ }^{2}$ \\ uddin.sore45@gmail.com, rahmat@gmail.com,mjufri@gmail.com, pataraiMl@gmail.com \\ Universitas Negeri Makassar, South Sulawesi, Indonesia, Jln. Bonto Langkasa Kampus Gunung Sari Baru, Postal Code 90222
}

Doi:10.5901/mjss.2016.v7n5p185

\section{Abstract}

The purpose of this study is to describe and analyze the effort to structure the governance of the bureaucracy of public service on Issuance of Travel Document System of the Republic of Indonesia (SPRI) or passport at the Makassar Class I Immigration Office, as well as to describe and explain the aspects that affect the governance structuring of Travel Document System of the Republic of Indonesia (SPRI) or passport in implementation of bureucracy reforms in Makassar Class I Immigration Office. This study is a qualitative study using phenomenological approach and techniques of collecting data through observation, in-depth interviews (depth interview), documentation, and key informant interaction with researcher, to get a deep overview and explanation about the progress of bureucracy reforms that guided by Act No. 6, 2011 on Immigration, Act 25, 2009 on Public Service, the Presidential Decree (Decree) Number 81 of 2010 on the Grand Design of Bureaucracy Reforms, 2010-2015 and the General Director of Immigration Number: IMI-891.GR.01.01 2008 on Standard Operating Procedure (SOP) of Issuance of Travel Document System of the Republic of Indonesia (SPRI) or passport, at the SPRI or passport issuance system of Makassar Class I Immigration Office. The study found that despite various efforts have been made by the government to improve the quality of pubic services to the public applicant through Immigration Act, the Public Service Act, as well as the General Director of Immigration regulations about the SOP, but untill now the complaints about the service is still often heard. Observing that problems, researcher used a device of regulations that published by the State Minister of Administrative Reform and Bureaucratic Reform (KepmenPAN / RB) Number. 12, 2011 on Guidelines for Governance Structuring and classical thinking of Weberian about bureaucracy rationality as theoretical base. Other findings from this research suggests that the government regulations are not sufficient to improve and enhance public services in order to implement the reforms of bureaucracy. Through this case study, researcher also found that aspects of the ethical-moral and values changes in the bureaucracy, are really influential and decisive the efforts to reform the bureaucracy and to create a fair, transparent and accountable governance.

Keywords: bureaucracy reforms, public service, governance, passport, immigration.

\section{Introduction}

Indonesia as a modern state should ideally make public services become a more important thing. The success of government agencies in providing public services, by looking at all activities of the agency, should be measured. And these measurements are not solely to the input of the program but more emphasis on outputs, processes, benefits and impacts.

Major challenges that faced by the government bureaucracy including immigration bureaucracy, is how they are able to implement the activities in an efficient and effective, because untill now, the bureaucracy stillidentified with the convoluted performances, too large structure, filled with collusion, corruption and nepotism, and no fixed standard. Bureaucracy for some people interpreted as a convoluted procedures, difficult and annoying. Negative view of bureaucracy emerged through a process of interaction in the pattern of relationship between bureaucracy to society, both at the level of policy making and in terms of implementation, particularly with regard to public services.

Based on Presidential Instruction No. 7, 1999 on Government Performance Accountability (AKIP), Decree of the Head of State Administration Institution No. 239 / IX / 6/8/2003 on Guidelines Reform of Preparation of Reporting 
Government Performance Accountability and Circular Letter of Administrative Reform and Bureaucratic Reform Minister Number: SE / 31 / M.PAM / 12/2004 on Stipulation Performance. All these show the government's efforts to improve the quality of public services through the development and implementation of accountability system that focuses on the performance which includes the preparation of the Strategic Plan, Performance Measurement, Performance Evaluation, and Reporting Performance in an integrated manner to be accountable for the successes or failures of the implementation of the basic tasks, functions and the organization's mission.

Rationally, according to Weber (cited in Albrow, 1989, pp. 33), bureaucracy has ideal characteristics, namely: the staff members personally free, only perform the duties of their personal positions. There is a clear hierarchy of positions. Positions functions is clearly defined. The officials appointed on a contract basis. They were chosen based on professional qualifications, ideally based on a diploma that obtained through examinations. They have a salary and usually with pension rights, tiered salaries according to the position in the hierarchy. Officials can always occupy his post and in certain circumstances it may be removed. The job position is his own field or main job. There is a career structure, and the promotion possibility is based on seniority and expertise and under consideration of the advantages (superior). Officials may not fit well with the position and with the resources that available at the position. He is subject to the disciplinary system and uniform control.

In the Weberian bureaucratic perspective that we can understand is a healthy bureaucracy, but in practice it has many obstacles that caused the bureaucracy is not working as it should, for example; when taking care of something at a government office and the procedures are cumbersome, slow or take a long time, require huge costs including additional costs, service less friendly, the practice of collusion, corruption and nepotism, and others. Researchers argue that the low moral and ethical values of the bureaucracy that is constantly changing, become the reasons why the anomalies or irregularities always get space to breed in an office environment. This fact gives a hint that bureaucratic reform was necessary in order to change according to the demands and development of society. Reasons for reform or change according to Hughes (in Widaningrum, 2009, pp. 355) is in order: (1) to objectify a new approach for the better functioning of public services towards managerial rather than an administrative, (2) as a response to the handling scale and coverage task of government, (3) changes in the theory and economic problems, and (4) changes in the role of the private sector in public service impelementation.

The occurrence of obstacles in the bureaucratic reform, mainly are caused by; first, in the bureaucratic apparatus view, especially the career pattern is not running properly. For example, there are still a lot of officials placements do not use the principle of "knowledge and basic competention", but more viscous with proximity orientation or nepotism. Second, the widespread practice of "politicization of bureaucracy", causing the disorientation on professionalism and competence. Third, the design of government organizations tends to be obese, so it is not efficient and effective. Fourth, the small and slender structure of government organizations, and also flat structure that rely more on skill and competence as a functional power, until now has not been implemented as national policy in the field of institutional reform of the bureaucracy. Fifth, along with employee remuneration policy improvements, it has not shown any seriousness of government's political will to sets remuneration changes in each unit of government agencies. Sixth, the arrangement of the working facilities allocation on all state positions in a fair and equitable, still not be the cornerstone of a comprehensive policy to manage personnel resources professional and competence (Istianto, 2011, pp. 143).

Indonesian bureaucracy performance is still disappointing. In a survey conducted by Dwiyanto, et al (2008) even described that the achievements value of the bureaucracy in terms of productivity, quality of service, responsiveness, responsibility, and accountability of the bureaucracy are still very low. Even as quoted by Dwiyanto et al, according to The World Competitiveness Yearbook 1999, our bureaucracy competitive index ranking in terms of the quality of public services is still in the lowest position compared to 100 other countries in the world. The research proves that in the term of service orientation, our bureaucracies are still tend not fully devote time and energy to carry out the task of serving the people. Nearly $40 \%$ of bureaucrats who were respondents in the study stated that they have other jobs outside their job as the state apparatus. This condition automatically reduces their concentration to do their duties (Setiyono, 2004, pp. 131).

In a study entitled "Patrimonialism and Military Rule in Indonesia", Harold Crouch saw Indonesian bureaucracy still tend patterned patrimonial, where power is obtained and maintained by shifting loyality and support to the positions and material interests (World Politics, 1989). Political and Economic Risk Consultancy (PERC) based in Hong Kong has also conducted research on the bad image of the bureaucracy in Indonesia that Indonesia has always ranked at the bottom in terms of service bureaucracy. Even in 2009, Indonesia is second from the bottom after India which is the worst state bureaucracy services (Suara Merdeka, June 5, 2009). Results of the study also assesses bureaucratic institutions of Indonesia, including the worst and have not experienced any significant improvement (Soebhan, 2000).

Similarly, research conducted by the World Bank and Gadjah Mada University about the performance of public 
services by using a number of variables, including: justice (equity), responsiveness, efficiency of services, graft and rentseeking bureaucracy (Dwiyanto, et al, 2003). The results of Good Governance Survey 2002 conducted by the UGM can be used to describe the condition of public services in Indonesia are still laden with the interests of the bureaucracy.

Santoso (1993) and Masson (2006) in their research also have the same conclusion, that the organization of the bureaucracy in Indonesia since the days of empire, until the era of Old Order and the New Order and the reform era has yet to show the change, the bureucracy still implement what he called as "feudalistic bureaucracy style" (Istianto 2011: 75). Our bureaucracy still tend to be served rather than serve. Based on the observation conducted by Dwiyanto, et al, (2008: 193) shows that the apparatus is very discriminate in giving the greeting to the service user. Results of these observations, about 30 percent of public service users in West Sumatra, Yogyakarta and South Sulawesi have experienced discrimination in services conducted by the bureaucratic apparatus. One of the impact of bureaucratic behavior is the tendency to use the intermediaries for receiving services. Based on data from GDS 2006 showed that the percentage of residents who use intermediaries when taking care of service to get a driver's license (SIM) and Citizen Card (KTP) and Certificate of Land, was the type of service that the latter showed higher percentage, namely in Java reaches $57,50 \%$ and $66.50 \%$ for outside Java (Dwiyanto, 2011, pp. 89).

The research also conducted by Yuliana Paris, with the title Apparatus Ethics in Public Service (Case Jakarta Land Agency). This result indicates that although normatively the land services have been using Standard Operating Procedures Land Services (SPOOPP), but the practice of irregularities in the service still remains the case, such as; the use of public office for private gain through lobbying and negotiation with the land forces outside the established procedure (Yuliana Paris, 2007, pp. 237-238).

The negative impression and the crisis of confidence in the government (bureaucracy) is caused by the bureaucracy who during this time could not respond to the wishes of the community. The use of intermediaries in different types of public services is tend to make a deviation of bureaucracy, although on the one hand, the services users and service providers to benefit mutually, but on the other hand would be detrimental to other service users who are not using intermediaries. The old concept of bureaucracy then considered no longer able to adapt to the rapid of development of Indonesian society, so the survey of Political and Economic Risk Consultancy (PERC) on the efficiency of the bureaucracy in 12 Asian countries involving 1274 expatriates who working in the countries of North Asia and South America, ranks Singapore first, then followed by Hong Kong, Thailand, South Korea, Japan, Malaysia, Taiwan, Vietnam, China, Philippines, Indonesia, and India. Bureaucracy were originally designed with careful methodology - and therefore running slow - already unacceptable by consumers who require fast service, efficient, timely, and simple.

Democracy and globalization has affected the livelihood of the people to be able to adapt to the changing demands. The more intense increasing relations with the international community have a major impact on the territorial function of a state. Therefore, the reform of the bureaucracy and legislation in all areas including legislation in the field of people, goods and services traffic. Immigration is all about the people traffic who enter or exit the territory of Indonesia and the surveillance of foreigner presence and activities in the territory of the Republic of Indonesia. In principle, the immigration bureaucracy function is the service to the community, law enforcement and security. To carry out these functions required immigration policies that provide comfort and convenience that will provide good image as a nation that is orderly and civilized, because the immigration service is also a first leading place to be traced by foreigners who want to get into the sovereign territory of Indonesia.

As bureaucracy, immigration institution is an important and strategic instrument in the context of control and surveillance of foreigners that provide benefits for the nation and state, which is part of the organization of state administration in the implementation of government tasks for the provision of services and legal protection for the people, either Indonesian or foreign countries citizen. Since 1945, the provisions of immigration law in Indonesia formally do not change and develope significantly, because of the strong influence of the Dutch colonial law and not in accordance with the Indonesian national life. However, on March 31, 1992, Law No. 9 of 1992, the law on immigration that embedded with national spirit was born, which is the unification and codification of some provisions relating to immigration that were previously scattered in several provisions of the legislation. Then it was refined with the Immigration Act No. 6 in 2011 with the intention of fixing provisions that no longer compatible with the demands of the changes that occur at this time as stipulated in Law No. 25 of 2009 on Public Service.

Makassar Class I Immigration Office is a government agency in the form of Technical Implementation Unit (UPT) in charge and serves to provide immigration public services and an extension of the Directorate General of Immigration which is part of the Ministry of Justice and Human Rights of the Republic of Indonesia. This unit was formed to provide excellent public service to the community in easy, effective, efficient, economical, and on time way as a response to people's desire to have a passport with an effective and efficient services. The applicant also always want that the officer at the immigration office always perform quickly, accurately and inexpensively services Based on initial observations on 
the object of research, the researcher observed the implementation of the passport in Makassar Class I Immigration Office. Researcher then found that the public service on passport issuance has not run with the maximum; although the Standard Operating Procedure (SOP) has been published and implemented through the Directorate General of Immigration Regulation No. IMI-891.GR.01.01 in 2008, Standard Operating Procedure on Issuance of Travel Document System of the Republic of Indonesia (SPRI) or passport.

But the publication of the regulations about passport issuance SOP whose purpose is to response the wishes of the passport applicant on fast, efficient, timely, simple, and cheap service, still does not change the negative stigma about public services that implemented by the government. Lucky Karim in a dissertation entitled "Implementation of the Standard Operating Procedure for I Republic of Indonesia Travel License System (Passport) In Makassar Class I Immigration Office" concluded that although the SOP proved to make the service to be efficient, but efficiency is not exhaustive. There are still inefficiency in some technical things that affect overall service process (Karim 2014). In observation, researcher still found the public dissatisfaction with the services of passport issuance in Makassar Class I Immigration Office. In addition, researcher also found several customers who expressed their satisfactions on passport issuance service despite the costly services. Therefore, this study will also prove the assumption that service passports at Makassar Class I Immigration Office still found some obstacles in the process of structuring the governance. In an effort to test this assumption, this research uses the Weberian theory on rationality of bureaucracy $(1904,1905.1930)$, Yuliana Paris research (2007), the Minister of Administrative Reform and Bureaucratic Reform (KepmenPAN / RB) Number 12, 2011 on Guidelines for Structuring Procedures, and Lucky Karim (2014).

\subsection{Problems}

Based on the scope of the research mentioned above, then the main problem in this research probably is about the inoptimality implementation of bureaucratic reforms in passports issuance service at the Makassar Class I Immigration Office. It then creating various forms of violations of bureaucracy in the public service passports at the Immigration Office Class I Makassar. Therefore, the main problem is developed in two research questions:

1. How is the arrangement procedure of the passport issuance system in Makassar Class I Immigration Office?

2. What are the aspects that affect the structuring management of the passport system in Class I Immigration Office Makassar?

\section{Research Method}

This research is a descriptive study that aims to describe and clarify the social phenomena clearly from a number of focus that relate to the unique problems which are investigated. While based on a managed data in the study is qualitative data in the form of a symbol or criteria to declare the results to be analyzed. Thus, this research can be regarded as descriptive-qualitative research. Qualitative research, according to J. Moleong Lexy $(2005 ; 4)$ is research that aims to understand the phenomenon that is experienced by research subjects, for example: behavior, perceptions, motivations, actions and others. In this research, associated with values, emotions, and feelings and also the available datas comes from the reality of social life, as well as the limitations of existing research facilities and want to explore as much as possible of data on target in-depth study. Whereas Bogdan and Taylor argued that the method of qualitative research is a research procedure that produces descriptive datas in the form of words written or spoken of the people and observed behavior (Moleong, 2007: 3).

In addition, this study uses a case study approach. According to Robert E. Stake (1978: 5) in the journal article "Educational Researcher" titled The Case Study Method in Social Inquiry suggested that the case studies is a research method that is most commonly used in social research because epistemologically able to work in harmony with personal experience of the readers that led on a natural basis for generalizing.

This study took place in the Makassar Class I Immigration Office, Perintis Kemerdekaan Street, Sudiang, Makassar. The choice of location is based on the consideration that:

1. Based on information compiled by researcher, the average of passports issuance service at the Makassar Class I Immigration Office are about 200-250 applicants per day, and even then outside the holiday peak season or out of Hajj and Umrah season. If entering the holiday season or Hajj and Umrah, the applicant's passport services can reach 250-300 applicants every day.

2. Based on observations conducted by researcher, service passports issuance service at the Class I Makassar Immigration Office is still dominated by the applicant who take his passport through intermediaries or passport services brokers on the grounds faster, eventhough it costs is more expensive. The applicant was also granted 
an option to acquire a passport service by self services, but it took longer time even though they are in accordance with the prescribed rules.

Researchers have made observations for 4 months on Makassar Class I Immigration Office. The duration is long enough to make researcher familiar with the passport issuance officers at the office. Below is the framework of this research:

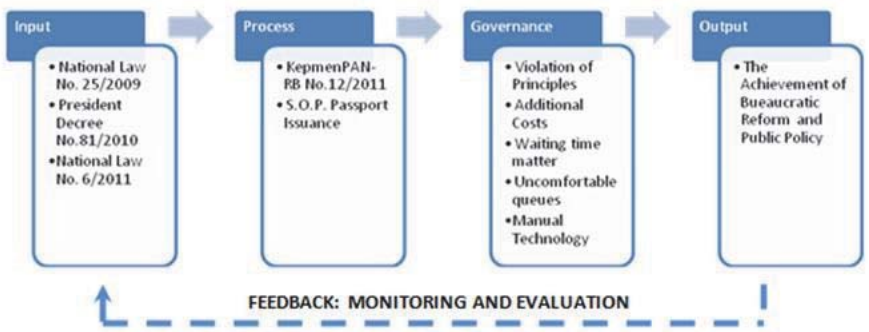

Figure 1. Conceptual Framework

\section{Results and Discussion}

Based on Figure 1, the research found that the system of passports issuance at the Makassar Class I Immigration Office troubled in the process of structuring the governance of which is not in accordance with the guidelines that issued by Kemenpan / RB (Ministry of Administrative Reform), where the process is influenced by several aspects which relativize SOP role in the process of passport issuance.

\subsection{The overview of the governance structuring process of passport issuance system}

The governance conceptually has two different dimensions, which are autonomy and capacity. Capacity and autonomy exclusively composed of resources and the degree of professionalism of the organizers of the bureaucracy, which is further away, these two things can then determine the quality of the management of which should ideally be independent. However, in reality the governance still become a difficult thing to define because it is associated with many complex things (Fukuyama 2013: 16). Meanwhile, according to Kemenpan/ RB (Ministry of Administrative Reform), the bureaucratic reform should meet the following principles: definitive, which the governance should have the boundaries, clear inputs and outputs. Sequence, in which the governance must consist of activities that in sequence accordang to space and time. Customers, where the governance should have a result. Value-added, which the governance should give the value-added to the receiver. Linkage, which the governance should be involved in the structure of an organization, and function of the cross, which the governance should include the multiple functions at once (KepmenPAN / RB No.12 2011). These principles constitute the ideal value of a governance process in a management sycle cycle as follows:

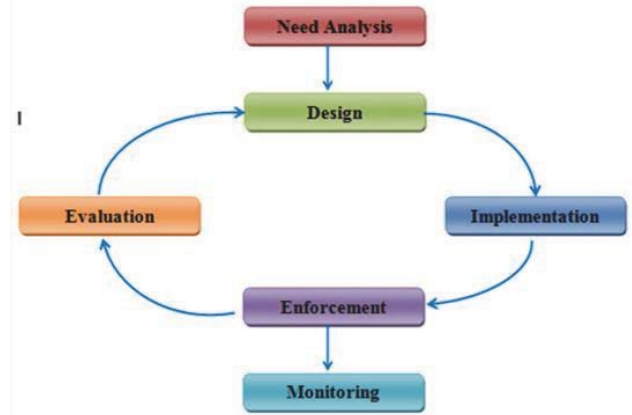

Figure 2. Governance Cycle based on KepemenPAN-RB/2011 
In reality of passport issuance in Makassar Class I Immigration Office, the implementation of SOP based on the General Director of the Immigration Regulation No. IMI-891.GR.01.01 of 2008, about the Standard Operating Procedure on the System of Republic of Indonesia Travel Document Issuance (SPRI) or passport and the use of information technology (IT or IT) computer and internet, does not change more the model of patrimonial in the past. Even though the satisfactions that come from several customer were also found in this research, but the dissatisfaction is still more felt. According to Weber, in patrimonia bureucracyl, service orientation is very dependent on the power pattern which is obtained and maintained by bureaucracy by shifting loyality and support to the positions and interests of the material. As a result, many jobs that do not achieve maximum results. That what Weber called as a "irrational" bureucracy. To create an advanced "rational" bureucracy, Weber developed eight ideal types that should be attached to the capacity of bureaucratic authority.These ideal types are strong emphasis on discipline aspect, therefore, Weber categorized the bureaucracy as a system of rational-legal authority; legal because it must comply with the rules of writing and can be viewed by anyone. Rational because it can be understood, studied, and has clear causal (Weber 1904-5, 1930).

In the context of governance structuring of the passport issuance system in Makassar Class I Immigration Office, rational-legal aspect that referred to Weber was not found. Makassar Class I Immigration Office which is subordinated to General Directorof Immigration of Law and Human Rights Ministry of Republic of Indonesia, can not perform strict control of the process of passports issuance because absolute power in the hands of the Director General of Immigration as the superordinate parties. As a result, the bureaucracy can not run with the rational, but rather because of the leader's desire and this state has been running for a long time. In this study, the situation gave rise to violations of professional ethics because of the low morality that caused by the fading of the degree of compliance and also because of the enactment of local values in the passport issuance bureaucracy.

\subsection{Moral-Ethical Aspects and Local-Values that affect Governance of Passport Issuance System}

Moral ethic plays an important role in the system of issuing passports at the Makassar Class I Immigration Office, because bureaucrats or officers of services who making the direct interaction with the public of passport applicants, do not adapt the eight ideal types of Weber. The service process that starting from planning, proposing programs, implementation, monitoring and evaluation of programs were closed implemented. The public can not see the process because everything is done according to the "central command of central government", this is because the Makassar Class I Immigration Office is the vertical agency, and not a part of the autonomous localgovernment. It is actually positive because it reflects an attitude of compliance and also the political will of bureaucratic leadership to serve the public. But the nuance becomes negative as such compliance is pseudo or as if obedient. In practice, some of the orders by the General Director of Immigration were breached by the bureaucracy of Makassar Class I Immigration Office. This can happen for example in case of deciding the cost of a passport issuance that vary greatly. This research found that, irrational bureaucratic system of issuing passports are caused by local values such as "sincerity", "sharing blessing" and so on. So further according to the findings of this research, public service users is also contributing to the irrationality of the bureaucratic system of issuing passports in the Makassar Class I Immigration Office.

\section{Conclusion}

In the Class I Makassar Immigration Office were found many distorted reality in SPRI or Passport Issuance System though the SOP and implementation of e-gov has been presented to support the establishment of bureaucratic reform and good governance. The research's findings stated that the public services that organized by Makassar Class I Immigration Office is still not sufficient to be regarded as a form of excellent service. This was caused by the classic problems that always surrounds, which is bureaucratic irrationality. Bureaucratic irrationality that was found, still seems to be relevant to Weber theorising about the characteristics of rational bureaucracy. The characteristics of service passports at the Makassar Class I Immigration Office, still convoluted, slow or take a long time, require huge costs including additional costs, service less friendly, the practice of collusion, corruption and nepotism, and so forth.

\section{References}

Ainur Rohman, Ahmad et al. (2008). Public Service Reform. Malang: Averroes Press.

Albrow, Martine. (1996). Bureaucracy. Yogyakarta: PT Tiara Wacana Yogya.

Anonim. (2008). Contemporary Administrative Sciences. Kencana: Jakarta.

Anonim. (2008). The Indonesian government bureaucracy in the Reform Era. Jakarta: Kencana Prenada. 
Anonim. (2011). Bring Back Public Trust through Reforms. Jakarta: Gramedia Pustaka Utama.

Dwiyanto, Agus. (2008). Public Bureaucracy Reform. Yogyakarta: Gadjah Mada University Press.

Istianto, Bambang. (2011). Democratization Bureaucracy. Jakarta: Mitra Wacana Media.

Katherine, L. Harrington. (1996). Ethics and Public Policy Analysis: Stakeholder Interest and Regulatory. Journal of Business Ethics, Netherlands: Kluwer Academic Publisher.

Law No.6 of 2011 concerning Immigration.

Law No. 25 of 2009 concerning Public Services.

Kurniawan, Agung. (2005). Transformation of the Public Service. Yogyakarta: Pembaruan.

Karim, Lucky. (2014). Implementation System Standard Operating Procedure for the Issuance of Travel Republic of Indonesia (Passport) On Class I Immigration Office Makassar. Unpublished Dissertation. Makassar: UNM.

Moleong, Lexy J. (1991). Qualitative Research Methodology. Bandung: PT Remaja Rosdakarya.

Muhammad, Fadel. (2008). Reiventing Local Government: Local Experince. Jakarta: PT. Elex Komputindo.

Mustopadidjaja AR. (2003). Management Process Public Policy Formulation, Implementation and Performance Evaluation, Institute of Public Administration, Republic of Indonesia. Jakarta: Duta Pertiwi Foundation.

Ndraha, Taliziduhu. (1997). Government Culture and Its Impact on Community Service, "Jurnal IImu Pemerintahan", 3rd Ed., Jakarta.

Osborne, David., and Gaebler, Ted. (1996). Reinventing Government. Jakarta: Pustaka Binaman Pressindo.

Paris, Yulianan. (2007). Apparatus Ethics in Public Service (In Case Land Agency of Jakarta). Dissertation.

Regulation of Ministry for the Empowerment of Satte Apparatus No.12 of 2011 concerning Management Planning Guidelines.

Regulation of the Director General of Immigration No. IMI-891.GR.01.01 of 2008 on Standard Operating Procedures (SOP) Travel Document Publishing System of the Republic of Indonesia.

Regulation of President (Perpres) No. 81 of 2010 concerning Grand Design Reform of Beraucracy 2010-2015.

Sj. Sumarto, Hetifah. (2009). Innovation, Participation and Good Governance (20 Initiative Innovative and Participative in Indonesia. Jakarta: Yayasan Obor Indonesia.

Suharmawijaya, Dadan S. (2006). Regional Autonomy and the Autonomy Award Two Provinces: set of Performance Monitoring and Evaluating Results District/City Province of Central Java and Yogyakarta. Semarang: JPIP.

Supriyanto, DR. Budi. (2009). Government Management. Tangerang: CV Media Brilian.

S. Pamudji. (1994). Professionalism State Apparatus to Improve Public Services "in Widya Praja, the Institute of Government Science Magazine No. 19, II/1994, pp. 21-22.

Setiyono, Budi. (1999). Bureaucracy in the Perspective of Politics and Administration, Center for Hariandja, Denny, B.C., Nan Arrogant Bureaucracy. Yogyakarta: Kanisius.

Sedarmayanti. (2010). Reform of Public Administration, Reforms and Future Leadership (Delivering Excellent Service and Good Governance. Bandung: Aditama.

Sugiyanto. (2004). Measuring the Performance of Public Policy (Question Correlational Against Actualization of Good Governance). Jurnal Good Governance, Vol.3, No: 1.

Thoha, Miftah (2007). Bureaucracy and Politics in Indonesia. Jakarta: PT Raja Grafindo Persada.

Tjandra, W. Riawan et al. (2005). Increased Capacity of Local Government Public Service. Yogyakarta: Pembaruan.

Weber, Max. (1930). the Protestan Ethics and The Spirit of Capitalism.

Weber, Max. (2009). Sociology. Yogyakarta: Pustaka Pelajar.

Zauhar, S. (1996). Administrative Reform: Concepts, Dimensions and Strategies. Jakarta: Bumi Aksara. 